\title{
Effects of Farmers' Field School on the Technical Efficiency of Cocoa Farmers in Nigeria
}

\author{
Adegboyega Oguntade \\ Department of Agricultural and Resource Economics \\ The Federal University of Technology, Akure, Nigeria \\ Tel: +234-803-4227-234Ｅ-mail:oguntadeade@yahoo.co.uk \\ Temitope Fatunmbi (Corresponding author) \\ Department of Agricultural and Resource Economics \\ The Federal University of Technology, Akure, Nigeria \\ Tel: +234-803-8207-726Ｅ-mail: topefatunmbi@gmail.com
}

Chris Okafor

Coco Plaza, Plot 254 Toure Drive, P.O. Box 78375

Dar es salaam, Tanzania

Tel: +255-784912-038Ｅ-mail: Chinenyeokafor2002@yahoo.com

Received: October 16, 2012 Accepted: October 30, 2012

doi:10.5296/jbls.v4i1.2531 URL: http://dx.doi.org/10.5296/jbls.v4i1.2531

\begin{abstract}
Nigeria is blessed with natural resources, among which cocoa is key. Over the years cocoa production has been declining and various interventions have been directed to improving production and productivity of cocoa in Nigeria. One of these interventions is the Farmers' Field School (FFS) approach. FFS employs a non formal approach to pass across new knowledge of improved and good agricultural practice to farmers. Therefore, the study aimed to examine the effects of Farmer Field School (FFS) on the Technical Efficiency (TE) of cocoa farmers in Cross River and Ondo States, Nigeria. The study areas for this study were the two major cocoa-producing states in Nigeria; Cross River and Ondo States. A total of 120 cocoa farmers were interviewed. This sample size was divided between both states equally. Thus, 60
\end{abstract}


respondents were selected randomly from around FFS communities for each state. Among the 60 respondents in each state, 30 were FFS participants while the other 30 were Non Farmer Field School (NFFS) participants. The study revealed that the FFS participants had an efficiency score of 0.84 while the NFFS participants' technical efficiency score was 0.77 . The study therefore concluded that the FFS participants were more efficient in the use of factors of production that their NFFS counterparts.

Keywords: Farmers' Field School, Efficiency, Cocoa, School, Slack, Nigeria

\section{Introduction}

Measurement of efficiency and performance of factors of production in Agriculture is very important to researchers as well as farmers. This is because resources are scarce and in some cases very expensive for farmers to purchase. Agrochemicals and labour as factors of production in cocoa business are very scarce. Therefore it is expedient for both the cocoa farmers and the researchers to know whether the cocoa output justify the resources expended on it. Studies have shown that the main problem identified by cocoa farmers was low yield, which was attributed to several factors (Dormon, Huis, Leeuwis, Obeng-Ofori and Sakyi-Dawson, 2004). Factors of production are said to be productive, if such factor is efficient both in physical and technical terms. Tchale (2009); Chirwa (2007); Mochebelele and Winter-Nelson (2000); Wadud and White (2000); Helfand (2004); Shanmugam and Venkataramani, 2006) amongst others have sought to estimate Technical Efficiency (TE) and its potential determinants in the agricultural sector. Binam et al. (2004) in examining the factors influencing technical efficiency of groundnut and maize farmers in Cameroon observed an average efficiency of $73 \%$ and $77 \%$ for the two crops, after controlling for environmental effects. Heshmati and Mulugeta (1996) observed a mean TE of 65\% for Ugandan matoke producing farms.

In the cocoa sub-sector, Binam, Gockowski and Nkamleu (2008) studied the determinants of technical efficiencies (TE) among cocoa producing communities in West African countries. Using stochastic frontier model and the Meta-stochastic frontier analysis, they estimated TEs for West African Cocoa producing countries and indicated that Nigeria was the most efficient with a TE of $74 \%$ and Ghana the least efficient with TE of 44\%. Richman, (2010) reported that, the mean technical efficiency among cocoa farmers' in Ghana was 0.442 in 2005/2006 cocoa season. This estimate is same as those observed in Binam et al (2008). This suggests that Ghanaian cocoa farmers produce only $44.2 \%$ of the efficient output or are about $56 \%$ away from the efficient frontier. This shows that the observed efficiency level of 0.44 for Ghana is lower than those observed in other cocoa producing West African countries. For instance Amos (2007) observed a TE of 0.72 in Ondo State Nigeria and Binam et al (2008) observed 0.74 among Nigerian cocoa farmers. The averages for Cameroun and Côte d'Ivoire were 0.65 and 0.58 respectively (Binam et al, 2008).

Studies by Binam et al, (2008) further showed that, the greatest share of productivity is due to the labour and farm size in Cameroon, farm size, and tree age in Ghana, farm size, labour and tree age in Nigeria and in Cote d'Ivoire. Whereas in West and Central Africa countries, the greatest share of productivity is generally due to the farm size, labour and the age of the 
cocoa farm. In the same study by Amos (2007), it was revealed that, the technical efficiencies (TE) among smallholders cocoa farmers in Nigeria ranged between 0.11 and 0.91 . Thus, it could be observed that there was presence of technical inefficiency effects in cocoa production in the study area.

In 2001, Sustainable Tree Crop Programme (STCP) of International Institute of Tropical Agriculture (IITA) commenced the implementation of a Farmer Field School (FFS) in selected cocoa producing communities on a pilot basis. The purpose is the transfer of the required good agricultural practices needed for improved cocoa production to farmers through the farmer field schools. A FFS consists of a group of farmers (usually 30) with a common interest who get together regularly to study the "how and why" of a particular aspect of agricultural production.

According to Braun et al. (2006), FFS is suited for field studies requiring specific hands-on management skills and conceptual understanding. The Farmers' Field School (FFS) consist of certain core elements (Braun, Jiggins, Röling, van den Berg and Snijders, 2006; Thiele, Nelson and Sherwood, 2001). These are the group of people with a common interest such as acquisition of technology/expertise, the farm which provides most of the training materials, the facilitator who has some technical knowledge of the subject matter and the curriculum which usually follow the natural cycle of the agricultural production under consideration. FFS had been used previously in Indonesia, Cambodia, China, India, Lao PDR, Philippines, Sri Lanka and Vietnam to address various problems in agricultural production (Braun et al., 2006; Tripp, Wijeratne and Piyadasa, 2005)

An evaluation of the impact of FFS was carried out by STCP in 2009.The evaluation covered impact of FFS on output agricultural practices, and knowledge of Integrated Crop and Pest Management by the cocoa farmers in Cross-river and Ondo States. The FFSs were directed at promoting the spread of Good Agricultural Practices (GAP) in cocoa production. Therefore this study addressed the effect of FFS on the Technical efficiency of cocoa farmers. The specific objectives of this study are to compare the Technical Efficiencies of FFS and non- FFS cocoa farmers as well as estimate and compare the level of inputs used by the two groups of farmers.

\section{Materials and Methods}

\subsection{Study Area and Sample Size}

The study covered the two major cocoa-producing states in Nigeria; Cross River and Ondo States (Hamzat, Olaiya, Adedeji, and Sanusi, 2006; MANR, 2006). In Ondo State, seven Local Government Areas (LGAs) were purposively selected based on their level of cocoa production and, more especially, their participation in FFS. These LGAs are Akure North, Idanre, Ifedore, Ile-Oluji/Oke Igbo, Odigbo, Ondo East and Ondo West LGAs. In Cross River State, four LGAs (Akampka, Boki, Obubra and Obudu) were purposively selected for the study based on the same consideration as in the case of Ondo State.

A total of 120 cocoa farmers were interviewed. This was divided between both states equally. Thus, 60 respondents were selected across the LGAs in each of the states. Among the 60 
respondents in each state, 30 were FFS participants while the other 30 were NFFS participants.

\subsection{Data Collection}

The primary data set used in this study was collected by administering a structured questionnaire on sampled cocoa farmers. Information was sought on age, household size, farming experience, farm size of the cocoa farmers; farm input use and output, among others. While the total number of farmers covered by the study was 60 per state, the total number of farms covered for the purpose of measuring farm sizes with the GPS and tree counting through the laying of transects was more than 60 since some of the farmers have more than one cocoa farm. Hand held GPS was deployed to collect some farm specific characteristics. Specifically GPS was used to measure the distance of farmers' homesteads to their cocoa farms. It was also used to estimate the area/size of each cocoa farm through a perimeter walk. The total area estimated by GPS was then compared with farmers own estimate. In order to estimate the number of cocoa trees and shade trees per hectare, three transects were laid on each cocoa farm and the number of cocoa trees were counted in each of the transect. The number of the cocoa trees in the three transects put together was extrapolated to arrive at the number of cocoa trees per hectare. The estimated number of cocoa trees per hectare was multiplied by the GPS estimated area of cocoa farm to arrive at the total number of cocoa trees on the farm. Similarly, in each transect the number of shade trees were counted and this was extrapolated to arrive at the number of shade trees per hectare. A non cocoa tree on a cocoa farm is considered a shade tree when its canopy is higher than that of the cocoa tree. The enumerators that were deployed to carry out this exercise were properly trained. The questionnaire used was pretested and amended as necessary.

\subsection{Method of Data Analysis}

The data analytical techniques used in this study are descriptive statistics and Data Envelopment Analysis (DEA) model. Cocoa farmers' socioeconomic and farm specific characteristics such as age, income from cocoa, income from non-cocoa production, number of cocoa trees, number of shade trees, etc. were examined using descriptive statistics. DEA model was employed to ascertain the productivity as well as technical efficiency levels of the cocoa farmers.

DEA is a multi-factor productivity analysis model for measuring the relative efficiencies of a homogenous set of decision making units (DMUs) that is, in this case cocoa farmers. Coelli (1995) indicated that the two main advantages of DEA are that it does not require the assumption of a functional form to specify the relationship between inputs and outputs and it does not require the distributional assumption of the inefficiency term. The former implies that one can avoid unnecessary restrictions about functional form that can affect the analysis and distort efficiency measures (Fraser and Cordina, 1999). . Coelli, Rao and Battese (1998), stated that constant returns to scale (CRS) DEA model is appropriate only when the farm is operating at an optimal scale. This is however assumed to be impossible in a developing country such as Nigeria due to many reasons which include financial constraints, imperfect competition, and inadequate farm inputs, etc. A variable return to scale (VRS) DEA is more flexible and envelops the data in a tighter way than the CRS DEA. The VRS DEA model was 
hence developed by Banker, Charnes and Cooper (1984).

An input oriented VRS DEA model was used in this study to estimate the technical efficiency of cocoa farms in the study area. Following Coelli et al. (1998), an input oriented variable return to scale DEA model for estimation of technical efficiency is specified as:

$\operatorname{Min} \Theta, \lambda \Theta$

Subject to: $-\mathrm{yi}+\mathrm{Y} \lambda \geq 0$

$$
\begin{aligned}
& \Theta x i-X \lambda \geq 0 \\
& \text { N1/ } \lambda=1 \\
& \lambda \geq 0
\end{aligned}
$$

where

$\mathrm{Y}=$ cocoa output matrix for $\mathrm{N}$ farms.

$\Theta=$ the input technical efficiency score having a value $0 \leq \Theta \leq 1$.

$\mathrm{X}=$ an input matrix for $\mathrm{N}$ farms.

$\lambda=\mathrm{N}$ byl vector of weights which defines the linear combination of the peers of $\mathrm{i}^{\text {th }}$ farm.

$y_{i}=$ quantity of cocoa output of $i^{\text {th }}$ farm $(\mathrm{kg})$

The inputs (X) considered are size of cocoa farm (hectares), cost of hired labour (Naira), cost of fungicide (Naira) and cost of insecticide (Naira).

\section{Results and Discussions}

\subsection{Descriptive Statistics of Key Variables}

Table 1 describes the key characteristics of cocoa farmers in the study area. From the table, the mean age of the cocoa farmers was about 55 years for the FFS participants while that of the NFFS participants was approximately 56 years. From this result, it could be seen that the difference in mean ages of these two groups is not much, such that the mean age for the two groups of farmers combined was 55.03 years. In Nigeria, household size is an important factor in agribusiness. This is because family labour is very important to these small holdings (World Bank, 2008). This study reveals that the FFS farmers in Nigeria had an average household size of 6 individuals while results from the NFFS reveal that the mean household size was 7 . It could also be seen here that the difference between the mean household sizes is not much. Farmers' level of education as shown in Table 1 reveals that FFS farmers had a mean value of 8 years, while their NFFS counterpart had a mean of 7 . The mean age of cocoa trees on the sampled farms was 25.83years while the mean size of those cocoa farms was 2.62 ha (GPS estimate). This indicates that most cocoa enterprises in Nigeria are small holdings. A survey of farmer's estimate of farm size was done to see if there would be disparities between the farmer's estimates and the GPS estimates of farm size. Interestingly, Table 1 shows that cocoa farmers' estimate of their farm size gave a mean farm size of 7.26 ha, which is almost three 
times higher than the GPS estimate. Effect of distance from homestead to the farm on cocoa output may be positive or negative. Farmers tend to search for virgin lands to cultivate in attempt to secure more fertile and hence productive land. Such lands are necessarily far away from the homestead. Thus cocoa farms that are far away from the homestead should ordinarily be the more fertile and hence more productive. Hence a positive relationship between distance and cocoa output could be expected. On the other hand, a negative relationship between distance and cocoa output may be hypothesized because farmers and hired labour may have to trek long distances before getting to such farms. This may discourage the farmers and, especially, hired labour leading to inadequate and untimely attention being given to the farms. Inadequate and untimely attention may result in low output (Ofuoku \& Ebewor, 2012). The mean distance from the farmers' homestead to the farm was $19.56 \mathrm{~km}$ with a standard deviation of $101.81 \mathrm{~km}$. The mean distance from the farmers' homestead to the farm for the NFFS farmers was higher than that of the FFS farmers. There were few cases of farms being located at very far distances from the homestead. The relationship between cocoa output and total number of shade trees may be negative due to the fact that high density of shade trees on cocoa farm may promote fungi infection which in turn reduces output. However, given the various benefits of shade trees (Asare, 2005), the relationship between total number of shade trees and cocoa output may be positive. From Table 1, the mean number of shade trees per ha of cocoa farm was 208.96. Table 1 also reveal that the mean yield of cocoa for the FFS farmers in the study area was $550.43 \mathrm{~kg} / \mathrm{ha}$, while the mean cocoa yield of the NFFS farmers was $861.06 \mathrm{~kg} / \mathrm{ha}$. Though both groups had almost the same natural production characteristics, it is amazing to see that the cocoa yield of the NFFS farmers was more than that of the FFS farmers.

Table 1. Socioeconomic Characteristics of Cocoa Farmers in the Study area

\begin{tabular}{|l|r|r|r|r|r|r|}
\hline & \multicolumn{2}{|c|}{ FFS } & \multicolumn{2}{|c|}{ NFFS } & \multicolumn{2}{c|}{ Total } \\
\hline & Mean & Std. Dev & Mean & Std. Dev & Mean & Std. Dev \\
\hline Age(Yrs.) & 54.38 & 14.22 & 55.67 & 14.04 & 55.03 & 14.08 \\
\hline Household Size & 6.47 & 2.3 & 6.82 & 2.29 & 6.64 & 2.29 \\
\hline Education (Yrs) & 8.05 & 5.06 & 7 & 4.18 & 7.53 & 4.65 \\
\hline Age of Cocoa Trees (Yrs) & 25.78 & 16.51 & 25.88 & 15.34 & 25.83 & 15.87 \\
\hline Cocoa Farm Size (GPS estimate) (ha) & 2.61 & 2.44 & 2.63 & 2.13 & 2.62 & 2.28 \\
\hline Cocoa Farm Size (farmers' estimate) & 7.55 & 7.5 & 6.97 & 8.21 & 7.26 & 7.84 \\
\hline Distance from home to Farm & 14.77 & 60.07 & 24.36 & 131.35 & 19.56 & 101.81 \\
\hline Shade Trees per hectare (Number/ha) & 241.25 & 186.43 & 176.67 & 184.5 & 208.96 & 187.51 \\
\hline Cocoa Output per hectare (kg/ha) & 550.43 & 532.42 & 861.06 & 952.67 & 705.75 & 784.12 \\
\hline
\end{tabular}

Source: Field Data (2009)

\subsection{Cocoa Farmers' Efficiency Score}

Input oriented variable return to scale DEA model was used in this analysis to estimate the technical efficiency of cocoa farms. In addition, descriptive analysis was done to compare the result of the DEA analysis. For the purpose of this discussion we only considered the VRSTE output. The VRSTE output showed that FFS farmers had a mean technical efficiency of 0.84 
while the NFFS farmers' mean technical efficiency was 0.77 . This indicates that FFS farmers are more technically efficient than the NFFS farmers, (see Table 2). In Table 1, it was shown that the NFFS participants had a higher yield, however, yield as a means of measuring productivity only look at one input and the only output i.e. kilogram of cocoa produced per hectare. The technical efficiency calculated in this section takes into consideration the various inputs that go into cocoa production as well as the relationships between these inputs. It determines the optimum input-output combination based on the existing technology that is being used by the farmers in the sample and compares the performance of each farmer with this optimum. Based on this comparison, it determines the efficient and non-efficient farmers. In effect, the DEA provides information on the relative TE of all the farmers in the sample.

The yield per hectare as a measure of productivity is a partial analysis in that only one input i.e. land is taken into consideration. Whereas the DEA considers all the inputs - land, insecticide, fungicide and labour, simultaneously. Considering the amount of other inputs used by NFFS in relation with the quantity of cocoa produced, on almost the same amount of land, it could be seen that the NFFS participants use more agrochemicals. In summary, while the NFFS participants were able to obtain higher quantity of cocoa per hectare of land, the result of the DEA reveals that the FFS participants better optimized the use of inputs.

Table 2. Cocoa Farmers' Efficiency Score

\begin{tabular}{|l|l|}
\hline Training Category & VRSTE \\
\hline$F F S$ & 0.84 \\
\hline$N F F S$ & 0.77 \\
\hline
\end{tabular}

Source: Field Data (2009)

\subsection{Classification of Efficient farms}

An efficiency score of 1 indicates that a particular farm is efficient while a score less than 1 implies that the farm is inefficient. From Table 4, 73.33\% (i.e. 44 out of 60) of the FFS farmers had an efficient score of 1 , which implies that only $26.67 \%$ of the FFS farmers were inefficient. On the other hand, $60 \%$ (36 out of 60) of the farmers were efficient. This clearly shows that more FFS farmers were technically efficient compare with NFFS farmers.

Table 3. Classification of Efficient farms by Participation in Farmer Field School

\begin{tabular}{|l|l|l|l|}
\hline Farms & FFS (\%) & NFFS (\%) & TOTAL \\
\hline Efficient & 73.33 & 60.00 & 66.67 \\
\hline Non-efficient & 26.67 & 40.00 & 33.33 \\
\hline Total & 100.00 & 100.00 & 100.00 \\
\hline
\end{tabular}

Source: Field Data (2009)

\subsection{Excess Input Used}

Since a slack indicates excess of an input use, a farm can reduce its expenditure on an input by the amount of slack without reducing its output. Table 4 show that there are opportunities for some of the farms to reduce their expenditures without reducing their outputs. Farm size 
displayed a mean slack of 0.47 ha among the FFS farmers, while the NFFS farmers were using an excess of 0.29 ha of land for their farming operations. This conforms to the earlier result in which the yield per hectare was higher for NFFS than FFS. The FFS farmers spent an excess of 3925.73 on hired labour, while the NFFS farmers spent an excess of $\$ 10$ 682.35. FFS farmers spent an excess of $\$ 302.40$ on fungicide while the NFFS farmers spent an excess of $\$ 7$ 830.18. On insecticide, FFS farmers spent an excess of 3044.69 while the NFFS farmers spent an excess of 11 679.40. Overall, these findings reveal that the NFFS farmers had higher slacks for inputs, that is, utilize factors of production more excessively compared with FFS farmers. Specifically, the NFFS farmers used land more efficiently than FFS farmers while the FFS farmers used fungicide, insecticide and labour more efficiently.

Table 4. Mean Input Slack

\begin{tabular}{|c|c|c|c|c|}
\hline & \multicolumn{2}{|c|}{ Mean Slack } & \multicolumn{2}{|c|}{ Mean Input used } \\
\hline Input & FFS & NFFS & FFS & NFFS \\
\hline Farm Size (ha) & 0.47 & 0.29 & 2.61 & 2.63 \\
\hline Cost of Fungicide ( & 3902.40 & 7830.18 & 10380.50 & 15205.00 \\
\hline Cost of Insecticide( & 3044.69 & 11679.40 & 5813.58 & 20152.94 \\
\hline Cost of Hired Labour ( & 3925.73 & 10682.35 & 21513.33 & 39421.67 \\
\hline
\end{tabular}

Source: Field Data (2009)

\section{Conclusions and Recommendations}

From the study it was observed that NFFS farmers made use of significantly more insecticides and fungicides. FFS farmers had been trained to "optimise" the use of agrochemicals and to rely more on appropriate cultural practices like pruning of chupons and optimal shading level to control blackpod and mirids, the two major pests limiting the yield of cocoa in the study areas. The heavy use of these agrochemicals, irrespective of the effects on the environment, may have been responsible for higher yield per hectare recorded by the NFFS farmers compared with FFS farmers. The input oriented Data Envelopment Analysis, which was used to assess the relationship between cocoa output and all purchased inputs, namely; farm size, cost of hired labour, and the amounts spent on fungicide and insecticide, however shows that FFS farmers had a mean technical efficiency of 0.84 while the NFFS farmers' mean technical efficiency was 0.77 . This indicates that FFS farmers are more technically efficient than the NFFS farmers. More FFS farmers $(73.33 \%)$ were technically efficient compared with the NFFS farmers $(60.00 \%)$.

\section{References}

Arnoud Braun, Janice Jiggins, Niels Röling, Henk van den Berg \& Paul Snijders (2006), A Global Survey and Review of Farmer Field School Experiences; Report prepared for the International Livestock Research Institute (ILRI) Final Report, 12 June 2006

Banker, R. D., Charnes, A. \& Cooper W.W., (1984). "Some models for estimating technical 
and scale inefficiencies in data envelopment analysis". Management Science 30, 1078-92.

http://dx.doi.org/10.1287/mnsc.30.9.1078

Binam , J. M., Gockowski , J. \& Nkamleu, G.B. (2008). Technical efficiency and productivity potential of cocoa farmers in West African Countries: A Meta Frontier Approach, International Institute of Tropical Agriculture (IITA). Humid Forest Ecoregional Center

Chirwa, E. W., (2007). Sources of Technical Efficiency among Smallholder Maize Farmers in Southern Malawi, African Economic Research Consortium (AERC) Research Paper 172

Coelli T. J, Rao D. S. P, Battese G. E., (1998). An introduction to efficiency and productivity analysis. Kluwer Academic Publishers, $\quad$ Boston, 271. http://dx.doi.org/10.1007/978-1-4615-5493-6

Coelli, T. J., (1995), "Recent developments in frontier modeling and efficiency measurement" Australian Journal of Agricultural Economics, 39, 219-45. http://dx.doi.org/10.1111/j.1467-8489.1995.tb00552.x

Fraser, I. \& D. Cordina., (1999), “An application of data envelopment analysis to irrigated dairy farms in Northern Victoria, Australia" Paper presented to the 43rd Annual Conference of the Australian Agricultural and Resource Economics Society, Christchurch, January 20-22.

Folayan, J. A., Daramola, A .G. \& Oguntade, A.E. (2006). Structure and Performance Evaluation of Cocoa Marketing Institutions in South-Western Nigeria: An Economic Analysis. Journal of Food, Agriculture and Environment, 4(2), 123-128.

Heshmati, A. \& Mulugeta, Y., (1996). "Technical efficiency of the Ugandan matoke farms". Applied Economic Letters, 3, 491-94. http://dx.doi.org/10.1080/758540813

Hamzat, R. A., Olaiya, A. O., Adedeji, A. R., \& Sanusi, R. A., (2006). State of Cocoa Growing, Quality and Research In Nigeria: Need for Intervention. A Technical Presentation at the biannual partnership Programme of the World cocoa foundation (WCF). Brussels, Belgium. 16th and 18th May, 2006.

Ministry of Agriculture \& Natural Resources, (2006). Report on Cocoa in Cross River State of Nigeria. Calabar: MANR

Nkang, N. M., Ajah, E. A., Abang, S. O. \& Edet, E. O., (2009). Investment in Cocoa Production in Nigeria: A Cost and Return Analysis of Three Cocoa Production Management Systems in the Cross River State Cocoa Belt. Africa Journal of Food Agriculture Nutrition and Development, 9(2). http://dx.doi.org/10.4314/ajfand.v9i2.19223

Nkang, N. M., Abang, S. O., Akpan, O. E. \& Offem, K. J., (2006). Cointegration and Error Correction Modelling of Agricultural Export Trade in Nigeria: The case of Cocoa. Journal of Agriculture and Social Sciences, 2(4), 9-255.

Ofuoku, A. U. \& Ebewore, S. O., (2012). Effect of Settlement Patterns on Cassava Production in Delta State, Nigeria. Global Journal of Science Frontier Research Agriculture \& Biology 


\section{Macrothink}

Volume 12 Issue 3 Version 1.0 March 2012 Publisher: Global Journals Inc. (USA) Online ISSN: 2249-4626 \& Print ISSN: 0975-5896

Richard Asare. (2005), Cocoa agroforests in West Africa: a look at activities on preferred

trees in the farming systems Forest \& Landscape Working Papers no. 6-2005 ISBN 87-7903-191-9 published on www.SL.kvl.dk,

Tiaji, S. B., Hanrahan, C., \& Nicolas, C. (2005). Child Labor in West African Cocoa Production: Issues and U.S. Policy. CRS Report for Congress. Congressional Research Service.

Thiele, G., R. Nelson, O. Ortiz, \& S. Sherwood, (2001). Participatory research and training: ten lessons from the Farmer Field Schools (FFS) in the Andes. Currents, 4-11.

Tripp, R., M. Wijeratne \& H. Piyadasa, (2005). What Should We Expect From Farmer Field Schools? A Sri Lanka Case Study. World Development 33-10, 1705-1720.

Tchale, H., (2009). The efficiency of smallholder agriculture in Malawi, AFJARE, 3(2).

World Bank, (2008). World Development Report 2008: Agriculture for Development. Washington DC: World Bank

\section{Copyright Disclaimer}

Copyright reserved by the author(s).

This article is an open-access article distributed under the terms and conditions of the Creative Commons Attribution license (http://creativecommons.org/licenses/by/3.0/). 